This is the accepted manuscript (post-print version) of the article. As regards to content, the post-print version is identical to the final published version, but there may be differences in typography, layout, and copyediting. Please cite the published version:

Mohammed Ibrahim Shire (2020) Dialoguing and negotiating with AlShabaab: The role of clan elders as insider-partial mediators, Journal of Eastern African Studies, DOI: 10.1080/17531055.2020.1863099

\title{
Dialoguing and negotiating with Al-Shabaab: The role of clan elders as insider-partial mediators
}

\author{
Mohammed Ibrahim Shire* \\ "Institute of Criminal Justice Studies, University of Portsmouth
}

Email:warsame101@gmail.com; Twitter:@DrMIShire

Since 2015, Al-Shabaab and the Federal Government of Somalia (FGS) have been locked in a violent, protracted stalemate. There is little momentum to pursue a political settlement, with Al-Shabaab rejecting any overtures of dialogue. Drawing on theoretical perspectives from peace and conflict literature and key interviews with clan elders and Al-Shabaab defectors, this article explores two interconnected themes. First, Al-Shabaab's dynamic attitudes towards dialogue since the group's establishment; and second, how clan elders play diverse peaceseeking roles, negotiating between Al-Shabaab and FGS at the microlevel. The article highlights two important findings. First, Al-Shabaab was initially inclined toward dialogue but, following the death and defection of senior members, increasingly adopted an anti-negotiation stance. Second, whilst Al-Shabaab is obstinately refusing any dialogue on the macrolevel, at the microlevel, the group indirectly negotiates with the FGS and other actors using clan elders as interlocutors and facilitators. Finally, the article explores the idea that, instead of relying on foreign third-party mediators to resolve Somalia's protracted stalemate at the macrolevel, clan elders, as credible insider-partial mediators possessing locally sourced legitimacy and perceived integrity, have the capacity to help overcome the stalemate between Al-Shabaab and the FGS. 


\section{Introduction}

Aan wada hadalno waa aan heshiino - 'Let us talk' means 'let us solve our problems' - Somali proverb

Somalia remains embroiled in a protracted struggle between Harakat Al-Shabaab AlMujahideen (an Islamist non-state armed actor; henceforth, Al-Shabaab) and the Federal Government of Somalia (FGS) that has reached a perceived stalemate. Scholars argue that lack of ripeness for peace talks in Somalia hinders any prospect of a political settlement. ${ }^{1}$ Increasing calls have been made for FGS to break the stalemate and pursue a negotiated political settlement with Al-Shabaab, using clan elders as credible interlocutors and mediators. Yet no concerted efforts to this end have been made thus far. ${ }^{2}$ Somali clan elders have historically been the primary source of conflict mediation within Somali society. Perceived as an informal institution, clan elders are the only group that possesses legitimacy across the broad spectrum of Somali society, including both Al-Shabaab and FGS. They have been instrumental in several interventions, inter alia, brokering temporary ceasefires, acting as trustworthy guarantors for high- and lowranking Al-Shabaab defectors, and negotiating access to humanitarian deliveries in AlShabaab-controlled regions. ${ }^{3}$

\footnotetext{
${ }^{1}$ See Göldner-Ebenthal and Dudouet, "Dialogue with Salafi Jihadi”; Elmi and Aynte, "Somalia: The Case for Negotiating"; Toros and Harley, "Negotiations with Al-Shabaab"; The notion of 'ripeness' signals a moment when the conflict is ready to be solved through negotiations between dyads.

${ }^{2}$ Olojo, "Time to Consider Negotiating"; Ibrahim Shire, "Negotiating with Somalia's Al Shabab"

${ }^{3}$ Maruf and Joseph, Inside Al-Shabaab.
} 
Several in-depth studies have examined whether negotiating with designated terrorist groups can be an effective state policy. Some authors have argued that dialogue with militant groups that employ terrorist tactics can encourage other dissident groups to use terrorist strategies as an effective method to achieve political change. ${ }^{4}$ A RAND Corporation study that analysed 648 terrorist groups that existed between 1968 and 2006 concluded that $43 \%$ of terrorist campaigns ended with a negotiation settlement compared to $7 \%$ that ended with military success. ${ }^{5}$ For this reason, some authors argue that negotiation can lead to an end to violence, a transformation in the conflict, and offer pathways for such groups to pursue nonviolent options. ${ }^{6}$

Whilst commentators continue to surmise that clan elders could facilitate direct negotiations between Al-Shabaab and FGS to end the conflict in Somalia, there is limited research that empirically tests this proposition. This article aims to fill this gap, drawing on 33 semi-structured interviews conducted (in Somali) in early 2019 with high-ranking clan elders ( $n=7)$, Al-Shabaab defectors ( $n=7$ mid-ranking and $n=19$ former rank-and-file) based in Baidabo and Mogadishu, official and private resources, media reports (chronicling the defection process of two former senior Al-Shabaab members), and academic studies. It first explores Al-Shabaab's and FGS's dynamic trajectories towards dialogue at the macrolevel. Second, it investigates whether clan elders' capacity as credible facilitators is rooted in praxis and whether they can be effectively employed to transcend the impasse between Al-Shabaab and the FGS to reach a negotiated settlement.

\footnotetext{
${ }^{4}$ Crelinsten and Schmid, West. Responses to Terror.; Clutterbuck, "Negotiating with Terrorists."

${ }^{5}$ Jones and Libicki, How Terrorist Groups End.

${ }^{6}$ Carl, "Is It Possible”; Powell, Talking to Terrorists; Toros, “"We Don't Negotiate.”
} 
The article draws broadly from 'insider-partial' mediation, an emerging topic in peace mediation literature. Insider-partial mediators are individuals who are already involved in the conflict, and who receive legitimacy, respect, and credibility from both sides even though they are associated with one side. ${ }^{7}$ Clan elders are, in theory, credible intermediaries across the spectrum of Somali society and, ipso facto, are regarded as insider-partial mediators. ${ }^{8}$ They are often associated with the FGS, as they primarily reside in government-controlled territory.

This article empirically contributes to the peace and conflict-resolution literature in several ways. First, it maps Al-Shabaab's trajectory from an 'open to negotiation' to a 'no negotiation' stance. Second, it provides unprecedented microlevel insights into the varied insider roles clan elders adopt when engaging state and non-state actors, including Al-Shabaab and the FGS. Finally, drawing broadly from Audrey Cronin's concept of a 'sponsor' - which argues that third-party mediators are essential assets for successfully starting the pre-negotiating phase with terrorist groups ${ }^{9}-$ this article explores the prospect of clan elders acting as credible third-party intermediaries to soften Al-Shabaab's current intransigent no-negotiation stance, and enhance and sustain the dialogue required for formal negotiation to bring the violent insurgency to a conclusion.

The first part of this article appraises scholarly perspectives on pre-negotiation and insider mediation theories. The second section traces past (missed) opportunities to engage Al-Shabaab and discusses the factors that led the group to refuse any dialogue with the FGS. The third section empirically examines, at the microlevel, the different

\footnotetext{
${ }^{7}$ Svensson and Lindgren, "Peace from the Inside."

${ }^{8}$ Menkhaus, "Traditional Conflict Management."

${ }^{9}$ Cronin, How Terrorism Ends, 66.
} 
intermediary scenarios clan elders regularly engage in when dealing with Al-Shabaab and the FGS, from acting as guarantors for defectors to hostage negotiators. I conclude the article by evaluating the prospect of commencing pre-negotiations with Al-Shabaab using clan elders as early facilitators.

\section{Concepts and Cases}

\section{Definition}

Whilst the conceptual definition of terrorism remains heavily contested, this article defines it as 'threatened or actual use of illegal force and violence by a non-state actor to attain a political, economic, religious, or social goal through fear, coercion or intimidation'. ${ }^{10}$ What constitutes a 'terrorist organisation' is similarly contested. Scholars have often distinguished terrorist and insurgent organisations by the nature of the organisation, territorial control, and type of violence. Terrorist organisations are usually clandestine, do not hold any territory and primarily employ terrorism, whilst insurgent organisations often run proto-states, rarely operate underground, and frequently use both guerrilla and terrorist tactics. ${ }^{11}$ In this regard, Al-Shabaab, like the Afghan Taliban, is an insurgent organisation that employs terrorism as one part of its violent toolkit. Yet Al-Shabaab is designated as a 'terrorist organisation' by at least eight countries, including the United States (US) and the group's homeland, Somalia. In line with the definitional approach of most studies that explore dialoguing with 'proscribed terrorist organisations', this article defines a terrorist group as a group that employs terrorism as one of its tactics if not its primary tactic.

\footnotetext{
${ }^{10}$ LaFree and Dugan, "Introducing the Global Terrorism Database."

${ }^{11}$ de la Calle and Sánchez-Cuenca, "We Talk about Terrorism."
} 


\section{Pre-negotiation}

Scholars have concluded that terrorist groups usually come to an end as a result of a military victory, defection, local policing, or negotiated settlement with a state government. ${ }^{12}$ However, there is considerable disagreement regarding the efficacy of negotiating with designated terrorist groups. Cronin noted that only $18 \%$ of terrorist groups end via negotiation, ${ }^{13}$ whilst Jones and Libicki reported $43 \%,{ }^{14}$ with the discrepancy rooted in the authors' conceptualisation of what constitutes the 'end' of such a group. Cronin further explained that, should negotiation be pursued, it is important to utilise credible mediators early on as a means to initiate the pre-negotiation phase. $^{15}$

The majority of the peace and conflict-resolution literature categorises peace processes according to three phases: pre-negotiation, negotiation, and post negotiation. ${ }^{16}$ In the 1980s, notable scholars like Harold Saunders and Janice Gross Stein, developed a critical understanding of pre-negotiation. ${ }^{17}$ Pre-negotiation is a fluid and particularly challenging phase that contributes significantly to the overall negotiation process; ${ }^{18}$ according to Saunders, 'persuading parties to a conflict to commit to a negotiated settlement is even more complicated, time-consuming and difficult than reaching

\footnotetext{
${ }^{12}$ Cronin, How Terrorism Ends; Jones and Libicki, How Terrorist Groups End.

${ }^{13}$ Cronin, How Terrorism Ends.

${ }^{14}$ See note 7 above.

${ }^{15}$ See note 13 above.

${ }^{16}$ Höglund, Peace Negotiations.

${ }^{17}$ Saunders, "We Need a Larger Theory,"; Stein, "Getting to the Table"

${ }^{18}$ Saunders, "We Need a Larger Theory."
} 
agreement once negotiations have begun'. ${ }^{19}$ Pre-negotiation begins when one or more groups contemplate mediation or negotiation as an alternative means of achieving their objectives, and convey this to the group. ${ }^{20}$ At the point of initiation, typically during a protracted stalemate, this intention ceases being an intra-group secret and must be signalled somehow, beginning the path to mediation and direct negotiation.

Views on what is the most appropriate point at which to initiate negotiations with terrorist organisations vary, yet there is a growing consensus in the extant literature that third-party mediation significantly increases the prospect of successfully reaching this point. Touval points out that even in intricate conflicts such as Israel-Palestine, mediators can play a significant role in the development of a peace process, by helping to 'conclude "small" agreements [in] reducing the conflict'. ${ }^{21}$ Similarly, Cronin notes that mediation creates a 'safety net', moderates violence, and facilitates the progress of direct negotiation. ${ }^{22}$ Zartman and Faure regard mediation between states and non-state armed actors as 'generally necessary'; ${ }^{23}$ and Beardsley, ${ }^{24}$ who is sceptical about the usefulness of mediation in peace processes, acknowledged that 'mediation can be strictly better - to the disputing parties as well as to the international community - than the alternative of escalating hostilities'.

However, mediation's effectiveness is disputed on the grounds of bias, which remains a contentious issue in the literature. Scholars have debated the impact of a

\footnotetext{
${ }^{19}$ Saunders, "We Need a Larger Theory," 249.

${ }^{20}$ Butcher and Hallward, Underst. Int. Confl. Manag.

${ }^{21}$ Touval, The Peace Brokers, 331.

${ }^{22}$ Cronin, How Terrorism Ends, 65.

${ }^{23}$ Faure and Zartman, Negotiating with Terrorists, 12.

${ }^{24}$ Beardsley, The Mediation Dilemma, 178.
} 
mediator's bias on the mediation outcome; some have asserted that a mediator should be neutral towards the disputants, ${ }^{25}$ whilst others argue that biased mediators have a greater positive impact on the mediation outcome, ${ }^{26}$ and that the self-interest of mediators increases the prospects of a successful mediation. ${ }^{27}$ Beardsley indicates that third parties are motivated to mediate by direct benefits that can be acquired if the conflict is resolved, such as avoiding an eventual refugee crisis and humanitarian disasters. ${ }^{28}$ Thus, their bias would not detract from their desire to reach negotiation. Extant literature reveals that mediation in intractable conflicts has primarily been employed by external third-party mediators such as the United Nations (UN), regional organisations, and other multilateral organisations. Svensson and Lindgren found that outside mediators dominate mediation literature, whilst there is scant research focusing on insider mediators (third-party intermediaries that live in the territory of one of the conflicting parties). ${ }^{29}$ Richmond and MacGinty have highlighted the failures of outside mediations. ${ }^{30}$ Indeed, evidence reveals that $40 \%$ of the mediation facilitated by outside mediators has faced severe difficulties or was unsuccessful. ${ }^{31}$ The domination of external mediation in the literature can potentially be explained by its focus on the more

\footnotetext{
${ }^{25}$ Murray and Young, "The Intermediaries."

${ }^{26}$ Touval, The Peace Brokers; Carnevale, "Mediating from Strength."

${ }^{27}$ Groeneveld-Savisaar and Vuković, "Terror, Muscle, and Negotiation”; Beardsley, The Mediation Dilemma.

${ }^{28}$ The Mediation Dilemma.

${ }^{29}$ Svensson and Lindgren, "Peace from the Inside."

${ }^{30}$ Richmond and Mac Ginty, "Where Now for the Critique."

${ }^{31}$ Armengol, "The Principles of Mediation."
} 
visible aspects of high-powered diplomacy, inadvertently overstating their prominence because they are easier to research.

\section{Insider mediation}

A growing and developing body of mediation literature discusses insider mediators, who have played an invaluable role in preventing and resolving conflict, particularly in contexts where international peacebuilding architectures fail to reflect developing political and complex social realities containing urban violence or asymmetric conflicts. ${ }^{32}$

Wehr and Lederach articulated the current practice of the insider-partial mediator as a role that emerges from within the conflict situation itself. ${ }^{33}$ Based on the authors' experiences in Central America, where an emphasis on trust was crucial to the resolution of a large-scale conflict, they recommended a broadening of the theoretical concept of mediation to include intervention by insider-partial mediators who provide continuity within the community and possess insider knowledge of the conflict situation. ${ }^{34}$ Ury referred to these types of mediators as the 'Third Side', to mean the 'surrounding community... of people with close ties to one side or the other who speak up against violence and for dialogue and negotiation'. ${ }^{35}$

Studying the role of the insider-partial mediator, Svensson and Lindgren found that they bring significant local resources to peace processes, and supplement external

\footnotetext{
${ }^{32}$ Wennmann, "Negotiated Exits."

${ }^{33}$ Wehr and Lederach, "Mediating Conflict."

${ }^{34}$ Ibid.

${ }^{35}$ Ury, “Getting To Peace," 182.
} 
mediators. ${ }^{36}$ Whilst intervening external mediators are disconnected from the context or processes, insider-partial mediators are unique in their legitimacy because their relationship to the conflict encompasses more than a professional role. In addition to the functions they fulfil, the insider-partial mediators' role is defined by their identity and association; the trust accorded to them is acquired through longevity, being directly and indirectly embedded in local communities.

Whilst the participation of external mediators is formally requested, insider mediators, however, are most likely already engaged - formally or informally - in precarious situations of escalation and de-escalation at the local level. They do this as interest-bearing members of a group or community affected by conflict, escalation, tension, or violence, and pursuing a variety of conflict-resolution goals. Wehr and Lederach maintain that their capability and effectiveness is rooted in part in the nature of the complexities with which they are already familiar; ${ }^{37}$ their role can vary depending on the mandate, skills, and personalities they bring to their work. Despite this, the involvement of inside mediators is as low as $4 \%$ for armed conflict, and $9 \%$ for civil war, compared to outside mediation which is utilised in $96 \%$ and $91 \%$ of these scenarios, respectively. ${ }^{38}$

\section{Clan elders in Somalia}

Following the collapse of the central government in 1991 and the ensuing protracted conflict, Somalia witnessed parallel dispute-resolution processes. At the macrolevel, external third-party mediators (e.g., the UN, Kenya, Djibouti) have convened at least a

\footnotetext{
${ }^{36}$ See note 29 above.

${ }^{37}$ See note 33 above.

${ }^{38}$ See note 29 above.
} 
dozen peace conferences to resolve the crisis - only to produce unsustainable, incompetent and costly transitional dispensations - whilst at the microlevel, clan elders have filled the void of the Somali state by replacing the missing legal system with a customary, religiously inspired legal system, Xeer Soomaali. ${ }^{39}$

Somali society is a segmentary-lineage society divided into agnatic descent groups. Each Somali social unit (clan family, clan, subclan, primary lineage group, extended family) has different rank-based clan elders. In the juridico-political authority structure of the clan system, the term 'clan elder' varies by level, as they operate under a fluid hierarchical internal governance structure. For simplicity, they can be broadly organised into two distinct groups: high-level and low-level clan elders. High-level clan elders commonly have a hereditary position with a recognised mandate and exercise significant autonomy, whilst low-level clan elders usually represent the diya (blood money)-paying groups and are generally selected to 'take care of the daily activities of sub- and sub-sub-clan issues' ${ }^{40}$

A high-level clan elder (often called suldaan, ugaas, islaan, boqor, wabar, malaaq, imaam, or garaad, depending on the locality) serves as a titled head of a large clan family or clan, which usually occupies several districts or even a whole region. The role encompasses an authoritative dimension and is representative of clan unity in external relations. The high-level clan elder unites the segmentary divisions to negotiate the clan's territorial and political claims and derives his authority based on tradition and historical legitimacy. For example, the Marehan clan, who principally live in Somalia,

\footnotetext{
${ }^{39}$ Xeer has been passed from generation to generation, and the majority of the population in Somalia have used it to settle disputes, both before and after the arrival of European colonisers in the Horn of Africa.

${ }^{40}$ Gundel, “The Predicament of the'Oday,” 33.
} 
Kenya, and Ethiopia, are led by the ugaas guud (king). Since the clan lives in regions that are distant from each other (some as far as $1,000 \mathrm{~km}$ ), the ugaas guud is represented by regional ugaasyo and suldaano. As the most important conflict mediators in interand intra-clan relations, their status makes them birimageydo (untouchable) during periods of conflict. Even during the worst clan or political violence, targeting a highlevel clan elder is guaranteed to result in large-scale violent backlash from the targeted clan, a situation which Al-Shabaab strategically avoids.

On the practical level, examples are abound of high-level clan elders exercising their inherited legitimacy and authority to negotiate or facilitate consequential incidents at the local, regional, and international levels. At the local level, high-level Hawiye clan elders were influential in orchestrating short respites for the war-weary Mogadishu residents by mediating periodic truces between two prominent warlords, Ali Mahdi and Aideed. ${ }^{41}$ At the regional level, high-level Majerten and Habar Gidir clan elders in Galkayo were instrumental in brokering a long-lasting peace deal between two clanbased rebel factions in 1993. On the international level, a 2000 diplomatic spat between Djibouti and the self-declared state of Somaliland, northwestern Somalia, prompted Djibouti to close its borders with Somaliland. Subsequently, the Somaliland government sent a delegation of high-level clan elders to Djibouti to ease the tension. ${ }^{42}$ In the absence of a central government, Ken Menkhaus acknowledged that high-level clan elders 'have also assumed the role of diplomatic envoy to neighboring state authorities in Ethiopia and Kenya, working out ways to police banditry, smuggling, and spillover from local disputes'. ${ }^{43}$

\footnotetext{
${ }^{41}$ Amnesty International, "Somalia: A Human Rights Disaster."

${ }^{42}$ Interpeace, “A History of Mediationin.”

${ }^{43}$ Menkhaus, "Governance without Government in Somalia," 87.
} 
A low-level clan elder (often called nabaddoon or aqil ${ }^{44}$ ) is a functionary of an immediate sub-clan family and is usually appointed or elected by his sub-clan family. The role primarily encompasses engaging in low-level activities such as settling cases between individuals, mediating low-level conflicts, collecting and allocating imbursements.

Unlike a high-level clan elder, whose authority and legitimacy are tied to his title, a low-level clan elder operates at the community level, primarily due to his lowlevel position of segmentation, and as such, his legitimacy is not uniform and highly dependent on his constituents' views of the legality of their services in terms of the Xeer. ${ }^{45}$ Some low-level elders enjoy considerable authority and legitimacy from their sub-clan constituents and have, since 1991, played a significant role in dispute resolution and local governance by using the Xeer as a moral and legal framework for conflict resolution at the local level. ${ }^{46}$ Conversely, there are several low-level elders with tenuous legitimacy and non-existent authority. Reminiscent of colonial practice, some are created or co-opted by corrupt political actors and, as such, are derided and negatively perceived as political proxies ${ }^{47}$ For instance, the unpopular leader of

\footnotetext{
${ }^{44}$ Aqil (wise man in Arabic) is a salaried position introduced by the Khedivate of Egypt but applied in practice by the colonial administration in the British Somaliland. The colonial authorities in Italian Somaliland employed a similar effort by nominating loyal elders to salaried capo (head in Italian) positions. In contrast, nabaddoon (peace emissary in Somali) is a catch-all term introduced by the Siad Barre administration to substitute for clan-specific terms relating to elders.

${ }^{45}$ Logan, “The Roots of Resilience."

${ }^{46}$ See note 42 above.

${ }^{47}$ Hussein, "The Impact of the Role."
} 
Jubbaland, Ahmed Madobe, appointed several 'copy chiefs' in Jubbaland to nominate his list of parliamentary candidates. This was observed by a prominent nabaddoon, who remarked that, 'the well-known elders used to be few in number but now we are nearly $130 .{ }^{48}$ Similarly, Al-Shabaab has a habit of using low-level elders for propaganda purposes, and has involved low-level clan elders in grandiose ceremonies. ${ }^{49}$ Others, though, are regarded as opportunists, often 'stirring up conflicts' to collect large amounts of diya money. ${ }^{50}$ Consequently, many derided low-level clan elders - unlike the protected high-level clan elders - are threatened, kidnapped, or assassinated by AlShabaab and other political actors..$^{51}$

For simplicity, this article will henceforth use the term 'clan elder' to signify a high-level clan elder or a respected low-level elder that exhibits significant legitimacy and authority within their respective constituency and is generally respected by the wider Somali society.

\section{Al-Shabaab and the FGS: mapping missed negotiation opportunities}

Since Al-Shabaab's inception, the group has adopted different attitudes towards engaging in dialogue with the FGS, ranging from an initial willingness to enter talks to an extreme unwillingness to negotiate. This article contextualises the evolving dynamics of Al-Shabaab's negotiation stance into two distinct phases: the nationalist-jihadist

\footnotetext{
${ }^{48}$ Saferworld, "Forging Jubaland," 20.

${ }^{49}$ CA Mataan, "Shabaab oo caleemo saaray suldaan Mudulood ah," Caasimada, September 28, 2020, https://www.caasimada.net/sawirro-shabaab-oo-caleemo-saaray-suldaan-mudulood-ah ${ }^{50}$ DRC, “Gedo Region in Somalia”; Marchal, "A Few Provocative Remarks” 4.

${ }^{51}$ VOA, "Al-Shabaab oo dilay nabaddoon 93 jir ahaa," VOA, July 2, 2018, https://www.voasomali.com/a/4463372.html
} 
period (January 2007 - May 2008) and transnationalist-jihadist period (May 2008 - late 2020). The first phase corresponds with the emergence of Al-Shabaab as an autonomous militant group, up to the death of one of its most prominent founding members, Adan Hashi Farah Ayrow. The second phase encompasses the 'reinvention' of Al-Shabaab under the tenure of its most prominent emir, Ahmed Abdi Godane (also known as Mukhtar Abu Zubair), and the period following Godane's death.

\section{Phase one: nationalist-jihadist struggle}

Al-Shabaab was formed initially from the remnants of Al-Itihaad al-Islaamiya (AIAI), a national Islamist movement which surfaced following the onset of Somalia's civil war, capturing strategic locations, establishing control, and enacting strict measures that brought some semblance of civil security to previously lawless areas. Both AIAI and its heir, the Islamic Courts Union (ICU), were overcome by Ethiopian military invasions in 1996 and 2006, respectively, leaving only Al-Shabaab - an ICU affiliate - to take up the mantle of Islamist militarism. Under the authority of its reclusive military face, Ayrow, Al-Shabaab initially branded itself as a staunch nationalist-jihadist group fighting a Somali struggle to expel Ethiopian forces from Somalia.

Against the backdrop of the 'war on terror', Al-Shabaab's initial arrangements rested on the centripetal force of nationalism but were quickly stifled by a concerted, Western-driven propaganda campaign linking Al-Shabaab with the 'global jihad' movement. Indeed, commentators equated Ayrow to Abu Mus'ab al-Zarqawi - whose wanton extremism and grotesque violence forced Al-Qaeda to disassociate from him. ${ }^{52}$ The US considered Ayrow Al-Qaeda's 'top operative' in Somalia and subsequently designated Al-Shabaab as a Foreign Terrorist Organization in early 2008, at the zenith

\footnotetext{
${ }^{52}$ CTC, "A Profile of Aden Hashi."
} 
of Ethiopia's occupation in Somalia. Moreover, Al-Qaeda's leader, Osama bin Laden, hinted in mid-2006 that Al-Qaeda would continue fighting the US and its allies in several countries, including Somalia. ${ }^{53}$ This message, coupled with Ayrow's jihadist credentials and his reclusive habits, ${ }^{54}$ arguably created an enigmatic image of a wellconnected Al-Qaeda operative. ${ }^{55}$

However, whilst Ayrow's jihadist credentials have some merit, his status as a global jihadist and purported link with Al-Qaeda are flimsy, for several reasons. First, Fadil Harun's (also known as Fazul Harun; a seasoned Al-Qaeda operative) autobiography reveals that there were no organisational ties between Al-Shabaab and Al-Qaeda during the nationalist-jihadist period, and that many Al-Qaeda members were actively opposed to the formation of Al-Shabaab. ${ }^{56}$ Second, comparable to how the Bush administration (in)advertently inflated al-Zarqawi's importance from an inconsequential local thug who was deemed unfit to join Al-Qaeda to a lightning rod for the global jihadist movement and Al-Qaeda's point man in Iraq ${ }^{57}$ Ayrow's limited local objectives were eclipsed by the Western-driven narrative of supposed Al-Qaeda involvement. Ayrow did, however, selectively employ this externally designated badge

${ }^{53} \mathrm{BBC}$, "New Bin Laden message is released," $B B C$, June 30, 2006, http://news.bbc.co.uk/1/hi/world/middle_east/5131818.stm.

${ }^{54}$ In an BBC interview, Ayrow acknowledged travelling Afghanistan in the 1990s for military training but returned long before the US invasion. He might have met some Al-Qaeda operatives, but no substantial link has been made thus far.

${ }^{55}$ The US Treasury Department and the State Department did not have his picture until after his death, when several Somali websites circulated his image.

${ }^{56}$ Lahoud, "The Merger of Al-Shabab."

${ }^{57}$ Michael, "The Legend and Legacy." 
to his advantage, using it to intimidate his armed rivals, particularly the largely unpopular Mogadishu warlords. This is acknowledged in a Terrorism Research Center report suggesting that 'Ayro[w] is merely a recent phenomenon who is plying his supposed Al-Qaeda training camp experience to intimidate other Mogadishu warlords' ${ }^{58}$. Second, Ayrow's strategic actions were fundamentally linked to Somalia's clan system and he actively engaged his clan in the attainment of Al-Shabaab's primary goal, to end the Ethiopian occupation in Somalia. This clan engagement was evident in the weeks leading to his death, where he attempted to set up a local administration in his clan's stronghold in Dhusamareb and led reconciliation efforts between Al-Shabaab and other anti-Ethiopian militias, again represented by his Ayr clan members. ${ }^{59}$ Moreover, Ayrow relied extensively on his clan relatives in the diaspora to 'finance the Jihad [against the Ethiopian army]', and secure funding to purchase weapons. ${ }^{60}$ Third, Zakariye Ismail, a senior Al-Shabaab defector, distinguished the early Ayrow-led AlShabaab insurgency from the Godane-led movement, stating that they 'were fighting against the Ethiopian occupation forces and were motivated by nationalism...but things started going wrong after Ayrow's death, leading Godane and some hardliners to become tyrannical and veer away from Al-Shabaab's goals.' 61

${ }^{58}$ Terrorism Research Center, “2005 Terrorism Analysis,” 556.

${ }^{59}$ Dawladnimo, “Kaalin Intee la eg bay Maxkamaduhu ku lahaayeen howlihii sirdoon ee sababay dilkii Macalin Aadan Ceyroow?", Dawladnimo, May 9, 2008,

${ }^{60}$ Anita Sharma, "Somalis Receive Federal Prison Terms For Sending Money To Al-Shabab From San Diego," KBS, November 18, 2013, https://www.kpbs.org/news/2013/nov/18/threelocal-somalis-get-prison-terms-sending-money.

${ }^{61}$ Wardoon Media Center, “Zakariye wareysi al-shabaab,” Wardoon Media Center, June 22, 2015, https://www.youtube.com/watch?v=hD7UOfqD2uM. 
Under Ayrow, with his nationalist-jihadist tendencies, Al-Shabaab was more inclined to open up a dialogue with the Transitional Federal Government (TFG), stipulating only the removal of Ethiopian forces and the implementation of Sharia law. ${ }^{62}$ Indeed, Roland Marchal observed that Ayrow's 'ambition has always been to build an Islamic State in Somalia, not wage Jihad in Nairobi or in Washington, DC'. ${ }^{63}$ However, whilst the group undoubtedly contained maximalist and violent pan-Islamist members, the nationalist narrative drowned out any competing influence. As such, Al-Shabaab's incipient and flexible approach was regulated by its nationalistic aims. Being able to draw on deep-rooted Somali antipathy towards Ethiopia and revelling in public approval, the group engaged in internal mobilisation, increasing their ranks with thousands of local and diaspora nationalist volunteers. In a rare audio-recorded speech, released in early 2007, Ayrow urged ethnic Somalis - primarily the youth - to join the national struggle in liberating the country from 'the [Ethiopian] forces that invaded Somalia', and vowed to 'give his life for the liberation of the country'. ${ }^{64}$ Cautious in accentuating the group's limited objectives of liberating the country, Ayrow eschewed any reference to the global jihad narrative. His localised approach urged traditional religious leaders, including the despised ex-warlords and militia members, to spearhead the 'legitimate' struggle, whilst cautioning them to adhere to the asluubta dagaalka (ethics of war) by abjuring any attacks on innocent civilians. Dismayed with what was

\footnotetext{
${ }^{62}$ Yusuf Garaad, “Taariikh nololeedkii Aadan Xaashi Ceyroow,” BBC Somali, May 1, 2008, https://www.bbc.com/somali/news/story/2008/05/080501_ayro_profile.shtml ${ }^{63}$ Marchal, "A tentative assessment," 401.

${ }^{64}$ Qaasidiya, “Abaanduuliyaha Ciidamada Golaha Maxaakimta Sheekh Aadan Xaashi Ceyrow oo Farriin cod ah Markii ugu horeysay u soo diray Shacabka Soomaaliyeed," Qaasidiya, March 7, 2007, http://qaadisiya.com/view_contents.php?articleid=530.
} 
happening in Mogadishu, Ayrow forewarned that the 'armoured tentacles of Ethiopian occupation' would reach Hargaysa (Somaliland) and Bosaaso (Puntland) unless ‘we come together', and urged regional governments to participate in the national effort. ${ }^{65}$

Whilst Al-Shabaab did not openly call for negotiations with the TFG, the TFG categorically rejected any negotiations with the group. In 2007 and early 2008, AlShabaab pursued a strategy involving an escalation of asymmetric attacks on Ethiopian targets and rural land grabs. ${ }^{66}$ Against this backdrop of mounting pressure, the TFG showed little openness to engaging the group in dialogue and instead engaged the powerless Djibouti-based Alliance for the Re-Liberation of Somalia (ARS), one of two splinter groups of the defunct ICU. President Abdullahi Yusuf openly declared AlShabaab 'a global terrorist organisation' and stipulated that his embattled government would never 'negotiate with a terrorist group'. ${ }^{67}$ Yusuf's refusal to open a dialogue with Al-Shabaab is arguably a potentially critical juncture that was missed. ${ }^{68}$

\section{Phase two: transnationalist-jihadist struggle}

Following the death of Ayrow, Al-Shabaab underwent a series of dramatic changes enacted by Al-Shabaab's then-emir Godane, who reversed the slain military commander's efforts to mould the group as an Islamist-nationalist guerrilla army. A

${ }^{65}$ Aayaha, "Macalin Aadan Cayrow: Taangiga maanta Xamar taagan berri wuxuu tegayaa Bosaaso iyo Hargeysa," Aayaha, November 13,

2007, http://www.aayaha.com/viewpage.php?articleid=5684.

${ }^{66}$ Ibrahim Shire and Hersi, "Brothers in Arms."

${ }^{67}$ Carmooyin, "Alshabaab waa argagixiso wax wada hadal ahna lama galeyno," Carmooyin, April 15, 2008.

${ }^{68}$ Ibrahim Shire, "Negotiating with Somalia's Al Shabab." 
watershed moment was when Godane released his first audio message - a month after Ayrow's death - declaring personal allegiance to bin Laden and other Al-Qaeda operatives, articulating Al-Shabaab's new grand objectives that included the establishment of a worldwide caliphate, refusal of any negotiations with the 'ignorant secularists, nationalists, and all apostates', and affirming that Al-Shabaab fully subscribed to 'the vanguard of global jihad'. ${ }^{69}$ Showing little regard for local conditions in Al-Shabaab, Godane immediately shed the group's nationalist image and made clear his global jihad intentions that hinged on ambitions beyond the borders of Somalia. In September 2009, Godane formally stated the group's allegiance to bin Laden only for bin Laden to graciously refuse it. ${ }^{70}$ It took several years, and the demise of bin Laden, for Al-Shabaab to be recognised as an official Al-Qaeda affiliate.

With his focus on global jihad and international fighters, Godane paid little attention to maintaining national support, and instead, established a draconian style of governance that largely restricted the majority of society from performing their daily activities. Further, he repealed the lenient policies previously adopted by the group, and instead directly antagonised traditional religious groups by destroying sites of religious pilgrimage. ${ }^{71}$ These actions triggered a drastic decline in public approval for the group. Throughout 2007, bolstered by Ayrow's initial military victories, Al-Shabaab had been hugely popular in Somali society; however, in late 2008 (after Ayrow's death), Somali

${ }^{69}$ Biyokulule, "MYM Commander Shaykh Al-Zubayr Sends Message to Global Jihad Leaders," Biyokulule, June 4, 2008, http://www.biyokulule.com/view_content.php?articleid=1244.

${ }^{70}$ Lahoud, "The Merger of Al-Shabab."

${ }^{71}$ Hiiraan, "Kismayo: Somali fighters destroying shrines," Hiiraan Online, December 20, 2008, https://hiiraan.com/news2_rss/2008/Dec/kismayo_somali_fighters_destroying_shrines. $\operatorname{aspx}$ 
society was becoming increasingly troubled by Al-Shabaab's governance and its disregard for local objectives in favour of global jihad ambitions. ${ }^{72}$ Indeed, following the influx of internationalist fighters, the movement under Godane decidedly shifted its rhetoric to mirror Al-Qaeda's, shunning Somali nationalist rhetoric. ${ }^{73}$

With the group's change in scope came a hardened stance of refusing any negotiations based on the group's earlier conditions. Godane argued that negotiation amounted to 'apostasy' and that the only options for the Somali government were surrender or total annihilation. ${ }^{74}$ A 2009 leaked US diplomatic cable revealed a proposal by then Libyan leader Mu'ammar Gaddafi to mediate the different parties in Somalia, to which Godane responded that once 'a truly Islamic government' was established in Somalia, he would expand the campaign to other countries, including Libya. ${ }^{75}$ Following the end of Ethiopia's occupation of Somalia in 2009, and the subsequent creation of a new national united government that brought Al-Shabaab's erstwhile moderate partners to power, ${ }^{76}$ the new TFG administration rescinded the previous no-

\footnotetext{
${ }^{72}$ Menkhaus, "Non-State Actors."

${ }^{73}$ Shinn, "Al Shabaab's Foreign Threat."

${ }^{74}$ SITE, "Shabaab Leader Tells Somalis to Prepare for Islamic State," SITE Intelligence, July 13, 2009, https://ent.siteintelgroup.com/Jihadist-News/site-intel-group-7-13-09-shabaableader-audio-prepare-state.html.

${ }^{75}$ Tim Lister and Paul Cruickshank, "Ruthless leader aims to extend Al-Shabaab's reach," CNN, September 2, 2014, http://edition.cnn.com/2013/09/24/world/africa/al-shabaableader/index.html.

${ }^{76}$ Former ICU leader, Sharif Sheikh Ahmed, was elected president of Somalia. Sharif was the head of the Djibouti wing of the Alliance for the Re-Liberation of Somalia and negotiated a power-sharing deal with the TFG in November 2008.
} 
negotiation policy and called for 'dialogue with Al-Shabaab to end the conflict'. ${ }^{77}$ Although Somalia's parliament voted unanimously in April 2009 to institute the Sharia law, ${ }^{78} \mathrm{Al}$-Shabaab declared the Somali government an apostate regime and inexorably argued that talks could only commence once the new foreign forces (African Union Mission in Somalia (AMISOM)) had left the country and the TFG repented for their 'apostasy' by returning to the 'fold of Islam'. ${ }^{79}$

Despite Al-Shabaab's anti-dialogue rhetoric, some attempts were made to persuade the group to negotiate with the Somali government. In early 2009, a body of leading Somali religious leaders proposed to mediate between the government and AlShabaab, negotiate a ceasefire, and demand the full withdrawal of AMISOM troops; however, Al-Shabaab was sharply divided on this. ${ }^{80} \mathrm{~A}$ former Al-Shabaab commander stated that Godane made a unilateral decision to refuse the mediation proposal and banned any future mediated meetings. ${ }^{81}$ Indeed, Godane rejected many calls by the Somali government for a meaningful dialogue between 2010 and 2014. Moreover, any potential negotiations were severely hampered by Godane's violent purge of his most

${ }^{77}$ Al Jazeera, “Somali president urges 'dialogue'," Al Jazeera, February 7, 2009, https://www.aljazeera.com/news/2009/2/7/somali-president-urges-dialogue.

${ }^{78}$ Mohamed Ibrahim, “Somalia Adopts Islamic Law to Deter Insurgency,” The New York Times, April 18, 2009, https://www.nytimes.com/2009/04/19/world/africa/19somalia.html.

${ }^{79}$ Maxamed Xuseen, “Afhayeenka Al-Shabaab: 'Waan iska difaacaynaa weerar walba oo nooga yimaada Dowladda Soomaaliya iyo Mareykanka" Hiiraan Online, August 3, 2010, https://www.hiiraan.com/news/2010/mar/wararka_maanta8-9175.htm.

${ }^{80}$ Interviews with Al-Shabaab defectors, Mogadishu and Baidao, January 2019

${ }^{81}$ Maruf and Joseph, Inside Al-Shabaab, 107; Interview with former Al-Shabaab commander, Mogadishu, January 2019 
vociferous critics, including foreign members, which led senior members of the nationalist faction to defect, including Mukhtar Robow and Dahir Aweys. Even AlShabaab'a deputy leader Ibrahim Haji Jama (also known as Ibrahim al-Afghani), a staunch internationalist, penned an open letter to Al-Qaeda's leadership, co-signed by Robow and Aweys, strongly denouncing Godane's 'harsh and dictatorial treatments' including the 'undoing [of] Al-Shabaab's grassroots public support' ${ }^{82}$ - a condemnation which led to his death at the hands of pro-Godane forces in June $2013 .^{83}$

Following the group's loss of major urban centres in 2012, the targeted killing of Godane in 2014, and the weakening of the group following the internal purge, the prospect of a negotiated settlement was once again on the horizon. However, this was refused with renewed and reinvigorated rhetoric by Godane's protégé and successor, Ahmed Diriye (alternatively known as Abu Ubaidah), who asserted that no negotiations would take place until AMISOM troops had departed from Somalia and FGS repented for its 'apostasy'. ${ }^{84}$ With no evident change in the prospect of entering into dialogue,

${ }^{82}$ Ibrahim al-Afghani, "Urgent and Open Letter to Our Amiir Shaykh Ayman Al-Zawahiri," Islamic World Issues Study Center, April 8, 2013, https://www.scribd.com/doc/134649814/Urgent-and-Open-Letter-to-Our-AmiirShaykh-Ayman-al-Zawahiri.

${ }^{83}$ AFP, “Al Shabaab extremists kill two of their chiefs," France24, June 30, 2013, https://www.france24.com/en/20130630-somalia-al-shabaab-al-qaeda-islamistextremists-kill-two-top-commanders.

${ }^{84}$ Jay Akbar, "Leader of Somali terror group Al-Shabaab sends out call for fresh wave of terror attacks," Daily Mail, July 27, 2015, https://www.dailymail.co.uk/news/article3172449/There-no-solution-except-Jihad-path-Allah-Leader-Somali-terror-group-AlShabaab-sends-chilling-call-fresh-wave-terror-attacks-east-Africa.html. 
and a sustained capability for Al-Shabaab to conduct small- to large-scale attacks weekly, the struggle against insurgency reached an inevitable perceived stalemate in 2015, which persists to this day.

\section{Clan elders as interlocutors for peace negotiations at the microlevel}

Clan elders have conducted several interventions between Al-Shabaab and other agencies, enacting their prescribed role as peacemakers and respected mediators. These interventions have, included facilitating and serving as guarantors for high-level defections by prominent Al-Shabaab members; brokering temporary truces between AlShabaab and the Somali government; mediating the release of local and foreign workers abducted by Al-Shabaab; and negotiating access to humanitarian deliveries in AlShabaab-controlled areas. Pertinent examples of these types of intervention are discussed in more detail in the following subsections.

\section{Guarantors for disengaged Al-Shabaab members}

In the past, clan elders have facilitated the defection of several high-profile Al-Shabaab members. One such defection was Al-Shabaab's former spiritual leader, ${ }^{85}$ Hassan Dahir Aweys, who left the group in early 2013 after clashing with Godane. Initially, Aweys was reluctant to surrender, refusing to talk with the government. ${ }^{86}$ A clan elder who participated in the mediation explained that, 'Even though he was in a weak position, he

${ }^{85}$ Although Aweys professed to be the group's spiritual leader, other accounts suggest that he was demoted to just mujahid, a position which he shared with rank-and-file Al-Shabaab fighters.

${ }^{86}$ Accompanied by close aides, Aweys fled from Barawe in a boat. The ancient town became a flash point for Al-Shabaab frontline infighting between pro-Godane and pro-Afghani forces, leading to the eventual capture and execution of Afghani. 
[Aweys] refused to surrender and instead requested an army from his clan Ayr/Habar Gidir clan to fight with the government' ${ }^{87}$ However, following a pre-negotiation talk facilitated by the highest-ranking elder of the Ayr/Habar Gidir clan, Ugas Hasan, Aweys agreed to enter into direct negotiations with the Somali government. Following months of negotiations with government officials - facilitated and encouraged by Habar Gidir clan elders - Aweys finally surrendered in mid-2013, and has been in government custody since. ${ }^{88}$ Similarly, Mukhtar Robow, co-founder and former deputy leader of AlShabaab, surrendered to Somali authorities in 2017. Following a similar process, his Rahanweyn clan elders brokered a deal with FGS in return for Robow's defection. A clan elder who facilitated the process remarked that,
the process was shrouded in secrecy....as the clan elders and [the third-party] facilitators, we had to establish a common ground for both groups to talk with each other... We had the government's support, and we equally represented Robow [as his clan elders], and because of this transparency between both groups, the real negotiation ended as a success, and there were no obstacles. ${ }^{89}$

Mid-ranking and rank-and-file defectors interviewed for this study have reported a myriad of reasons for their defection, though the defection process commonly involved clan elders, directly or indirectly. Most rank-and-file defectors identified that their defections were facilitated by family members (mostly mothers), and those in government (mostly uncles and cousins), who put them in touch with their respective

\footnotetext{
${ }^{87}$ Interview with Habar Gidir clan elder, Mogadishu, January 2019.

${ }^{88}$ Halgan, "Odayaasha dhaqanka Mudug iyo Sh Xassan Daahir Aweys oo is afgarad buuxa gaaray," Halgan, June 26, 2013, http://halgan.net/2013/06/odayaasha-dhaqanka-mudug-iyosh-xassan-daahir-aweys-oo-is-afgarad-buuxa-gaaray.

${ }^{89}$ Interview with Rahanweyn clan elder, Baidabo, January 2019.
} 
clan elder to act as guarantor. ${ }^{90}$ The clan elders served as a vector that prevented the defector from being handed over to the National Intelligence and Security Agency (NISA) and tried in a military court. Virtually all defectors highlighted that the trust and respect they had for their clan elders enabled them to navigate the disengagement. Others added that they defected upon the instigation of their former Al-Shabaab commanders; this was the case for Mukhtar Robow, who encouraged a further 20 defectors..$^{91}$

Furthermore, the majority of mid-ranking defectors stated that male relatives played an essential role, arranging negotiations with clan elders to facilitate their return. One mid/high-ranking defector, who remains under house arrest in Mogadishu, stated that 'without my clan elders to guarantee my safe defection, I would have stayed with Al-Shabaab' ${ }^{92}$ Certainly, this is highlighted in the defection story of Al-Shabaab's former intelligence chief, Zakariye Ismail, who disengaged from the group in December 2014. Ismail surrendered to the traditional body of his clan's stronghold in the Gedo region of Jubbaland state. Some analysts at the time recognised this and called for FGS to utilise clan elders as part of the disengagement and negotiation process..$^{93}$

\footnotetext{
${ }^{90}$ Interviews with Al-Shabaab defectors, Mogadishu and Baidabo, January-February 2019.

${ }^{91}$ MGSE, "Letter Dated 7 November."

${ }^{92}$ Interview with former Al-Shabaab commander, Mogadishu, January 2019.

${ }^{93}$ Shukri Mohamed, "Somalia: Defection of Senior Al-Shabaab Official Rekindles Debate Over Amnesty Programme," Sabahi, January 2, 2015, https://allafrica.com/stories/201501050384.html.
} 


\section{Intermediaries for humanitarian delivery, hostage negotiation, and negotiated} truces

Clan elders have, in the past, negotiated for the release of many documented abductions by Al-Shabaab. Generally, state actors and international organisations refuse to deal directly with Al-Shabaab, so they employ clan elders to mediate. Other times, clan elders act on their own accord. In January 2012, two Kenyan government employees, Edward Yesse and Fredrick Wainaina, were abducted by Al-Shabaab from Gerile, Kenya, three months after Kenya's invasion in Somalia. ${ }^{94} \mathrm{~A}$ third hostage was identified as Kenyan-Somali Dekow Mohammed but was released after three days, following intervention by his clan elders. The Kenyan government refused to negotiate directly with Al-Shabaab and instead tasked Kenyan-Somali elders with resolving the matter. Following negotiations, the clan elders secured the two other hostages' release. ${ }^{95}$ Similarly, in December 2015 in Jubbaland state, Al-Shabaab released three aid workers following the quick intervention by Marehan clan elders. ${ }^{96}$ In 2019, the Kenyan government, building on past successes employing clan elders as credible interlocutors, sent a group of Somali elders from Mandera to negotiate the release of two Cuban

\footnotetext{
${ }^{94}$ In October 2011, Kenya mounted an invasion in southern Somalia ostensibly to launch a military offensive against Al-Shabaab.

${ }^{95}$ BBC, "Somalia's al-Shabab frees Kenya's Mule and Wainana," $B B C$, August 1, 2013, https://www.bbc.co.uk/news/world-africa-23529942.

${ }^{96}$ MCRS, “Somali Aid Workers Kidnapped In Gedo Have Been Freed”, MCRS, December 28, 2015, http://mogadishucenter.com/English/2015/12/28/somali-aid-workers-kidnapped-ingedo-have-been-freed.
} 
doctors abducted by Al-Shabaab. ${ }^{97}$

Perhaps the most daring intervention came when Al-Shabaab captured Gal'ad, a government-held town in Somalia's central region of Galgadud. Following the town's capture, Al-Shabaab was ready to publicly decapitate several hundred captured government soldiers. The town's clan elders immediately brokered a truce that prevented a massacre from occurring. One of the lead negotiators amongst the elders explained that he had brokered many truces between Al-Shabaab and former government troops, stating that "there has been a crisis in our country... lots of bloodshed[s]; neighbours and brothers fighting against each other... and as elders, it is our responsibility to do our part and help our people' ${ }^{98}$

Beyond hostage negotiating, clan elders played a key role in negotiating access to delivery of humanitarian aid in Al-Shabaab-controlled areas. Amidst the 2017 drought in Somalia, Al-Shabaab imposed a ban on humanitarian assistance in the areas they controlled, repeating a similar blockade they had imposed during the 2011 famine in Somalia and putting more than 2 million suffering people at risk. To circumvent the blockade, humanitarian agencies and FGS successfully employed religious and clan

${ }^{97}$ Translating Cuba, "Kenyan and Somali Elders Try to Negotiate Release of Kidnapped Cuban Doctors," Translating Cuba, April 16, 2019, https://translatingcuba.com/kenyan-and-somalielders-try-to-negotiate-release-of-kidnapped-cuban-doctors.

${ }^{98}$ Hamza Mohamed, "Somalia: Elders negotiate with al-Shabab over soldiers," Al Jazeera, November 24, 2016, https://www.aljazeera.com/indepth/features/2016/11/somalia-eldersnegotiate-al-shabab-soldiers-161116061954168.html. 
leaders to act as intermediaries in negotiating humanitarian access. ${ }^{99}$ Similar experiences were described by the clan elders interviewed for this study who were deployed as intermediaries in negotiations with Al-Shabaab during the 2011 famine and 2017 extreme drought. One remarked that, during the climax of the famine and the ongoing blockage of aid relief by Al-Shabaab, 'we went to Robow and placed considerable pressure on him to negotiate and allow international aid relief to reach our dying people and he accepted even though it went against the official position of his group [Al-Shabaab]'. ${ }^{100}$ All remarked that the legitimacy and credibility they were endowed with and the urgency of the unfolding famine motivated the group to derestrict access for humanitarian purposes and accept 'taxes' instead.

Finally, reminiscent of past practices during Somalia's tumultuous warlord-era of the 1990s, clan elders played a crucial role in facilitating truces between armed actors. Following frequent clashes between FGS and ASWJ forces in late 2014, the most senior elder of the Ayr/Habar Gidir clan successfully brokered a temporary ceasefire. ${ }^{101}$ Similarly, in early 2009 , Hawiye clan elders were successful in temporarily halting attacks between two Islamist militias. ${ }^{102}$ Also in early 2009 , following the

${ }^{99}$ Connor Gaffey, "Somalia's Drought Raises a Thorny Issue —-Talking to Al-Shabab," Newsweek, March 26, 2017, https://www.newsweek.com/somalia-drought-al-shabaabfamine-573856.

${ }^{100}$ Interview with Rahanweyn clan elder, Baidabo, January 2019.

${ }^{101}$ AA Warsame, "Xabad joojin la dhex dhigay ciidamada dowlada iyo kuwa Ahlusuna ee Galgaduud," Mareeg, December 15, 2014, https://mareeg.com/xabad-joojin-la-dhex-dhigayciidamada-dowlada-soomaaliya-iyo-kuwa-ahlusuna-ee-galgaduud/amp.

102 Mareeg, "Odayaasha Hawiye oo ku guuleystay kala qaadida Ciidamada is hor fadhiya," Mareeg, March 1, 2009, https://www.mareeg.com/fidsan.php?sid=10738\&tirsan=2. 
ousting of TFG forces from Baidabo by Al-Shabaab's deputy leader, Robow, clan elders were instrumental in persuading Robow to provide safe passage to the trapped government officials. Later, Rahanweyn clan elders intervened in the ensuing flareups by brokering a temporary truce between Al-Shabaab and TFG forces in the neighbouring city of Hudur. ${ }^{103}$ There are many examples of clan elders brokering temporary and permanent truces between opposing groups, from Habar Gidir and Majerten clan elders putting an end to the cyclical Puntland and Galmudug skirmishes in $2017,{ }^{104}$ to Habar Yonis clan elders facilitating a peace agreement between the Somaliland government and Colonel Aare's rebel group. ${ }^{105}$

\section{Underlying factors}

After establishing the varied roles clan elders already play as facilitators and mediators in resolving disputes between Somalia's warring parties at the microlevel, it is important to examine the attributes underpinning this phenomenon. I argue that clan elders are historically and traditionally endowed with three essential traits that enable them to undertake various capacities when dealing with different groups. The first is

${ }^{103}$ SMC, "Isgaarsiinta degmada Xudur oo maalintii labaad hawada ka maqan xili odayaasha gobolada Bay iyo Bakool ay bilaabeen dadalo lagu xalinayo dagaalo ka dhacay degmadaasi," Shabelle Media Network, February 12, 2009, http://shabelle.net/news/viewnews.asp?newsid=4672

${ }^{104}$ Maxamed Lakiman, "Puntland iyo Galmudug oo Maanta Gaalkcyo Heshiis Taarikh ah ku gaaray \& Issimadda Puntland oo goobjoog ahaa," Radio Daljir, December 17, 2017, https://www.daljir.com/puntland-iyo-galmudug-oo-maanta-gaalkcyo-heshiis-taarikhah-ku-gaaray-issimadda-puntland-oo-goobjoog-ahaa-dhegaysosawiro.

${ }^{105}$ MR, “Kornayl Caarre oo heshiis lagalay Somaliland," Mustaqbal Radio, January 1, 2020, https://www.mustaqbalradio.net/kornayl-caarre-oo-heshiis-lagalay-somaliland. 
accountability. Clan elders often do not perceive their mediation efforts as a 'job' but a social responsibility for the wellbeing of their communities. ${ }^{106}$ Their historical involvement in arbitrating conflict and upholding agreements has enabled them to play a central role in establishing legitimate institutions. They derive authority from having been chosen to represent their clans, and are answerable to them; this authority empowers them to make and enforce agreements and is integral to Somali clans being able to hold their kinspeople accountable for transgressions. ${ }^{107}$ Cognisant of the sentiments of their war-weary constituents, elders are motivated to find durable and peaceful solutions. As actors already having a stake in society and directly affected by the conflict themselves, their indigenous accountability automatically implies some level of responsibility.

The second element is trust. Scholars indicate that in societies with a relationaloriented understanding of trust, it is more difficult for outsiders to be accepted as mediators, whilst the insider mediator is not a detached facilitator but a party to the process of mediation and therefore must be trusted by all parties involved. ${ }^{108}$ This level of trust is exemplified in the role assumed by clan elders in Somalia. Typically, a Somali clan elder's rise to a position of influence is not always based on hereditary factors but acquired because of reputational factors - being an effective negotiator, an orator, a pious and wise elder, or a trusted mediator. ${ }^{109}$ Though clan elders collectively represent their respective clans, they are trusted by all sides due to the recognition they receive.

\footnotetext{
${ }^{106}$ Mir and Vimalarajah, "Tradition- \& Faith-Oriented Insider Mediators.”

${ }^{107}$ Bradbury and Healy, "Whose Peace Is It."

${ }^{108}$ Lee and Teh, "One Asian Perspective."

${ }^{109}$ Menkhaus, "Traditional Conflict Management.”
} 
Moreover, clan elders play a key role in countering violent extremist activities, as they are currently regarded as the best-functioning early warning network, since they are often the first to be warned about young people becoming radicalised, and first to be contacted by Al-Shabaab members who wish to defect. ${ }^{110}$ This trust is evident in the varied situations that clan elders are frequently engaged in. Virtually all (92\%) former mid-ranking and rank-and-file Al-Shabaab members interviewed for this study preferred clan elders to initiate their disengagement; a similar finding was reported by Botha and Abdille. ${ }^{111}$

The third trait is legitimacy. Insider mediators possess an inherent legitimacy that often places them in a more advantageous position than outsiders to mediate peace within and across their constituencies. ${ }^{112}$ Somali clan elders, as representatives of the clan governance system, wield a moral authority that is associated with immediate recognition of legitimacy. Al-Shabaab is aware of this. Following Godane's killing in 2014, Al-Shabaab reversed the exclusion of clan elders from their governance. The group realised that it needed the popular support of communities and could only acquire this if it extended a degree of respect and legitimacy to the clan elders. ${ }^{113}$ To acknowledge their legitimacy and moral authority, Al-Shabaab formed a Council of Clan Elders in 2016, cementing the co-option of their role within Al-Shabaab's governance system. ${ }^{114}$

\footnotetext{
${ }^{110}$ Gelot and Hansen, "They Are from within Us."

${ }^{111}$ Botha and Abdille, "Al-Shabaab Attitudes Towards Negotiations," 466.

${ }^{112}$ Roepstorff and Bernhard, "Insider Mediation in Peace Processes"

${ }^{113}$ Göldner-Ebenthal and Dudouet, "Dialogue with Salafi Jihadi Armed Groups,” 25.

${ }^{114}$ Sahan Africa, "Al-Shabaab as a Transnational Security Threat."
} 


\section{Opportunities for dialogue with Al-Shabaab at the macrolevel}

Against the backdrop of gradual progress and signs of hope in Somalia, including peaceful elections in 2012 and 2017, the campaign against Al-Shabaab remains at a perceived stalemate. The current counterterrorism strategy against the group, involving joint operations and US airstrikes, has done little to degrade Al-Shabaab. ${ }^{115}$ On the contrary, Al-Shabaab continues to maintain its operational capacity, staging attacks using both conventional and unconventional tactics including suicide bombings, roadside bombings, and assassinations of government officials and civilians in Somalia and neighbouring countries - mainly Kenya, Uganda, and Djibouti. The group's violent operations are exacerbated by the current refusal of the group to consider direct negotiations with FGS even though the FGS is seemingly ready for dialogue.

The need to transition from a violent stalemate to a negotiated settlement is increasingly pressing. The importance of clan elders in getting both sides to talk is advocated by Al-Shabaab defectors, clan elders, and the majority of Somali society, ${ }^{116}$ and echoed by many commentators. ${ }^{117}$ Indeed, Ugas Abdullah of the Gugundhabe clan expressed frustration at the relentless deadlocks during the early years of Somalia's civil war, stating that 'Somalia's [rebel] military leaders will never make peace...[only] the clan elders can finalise the [peace] process'. ${ }^{118}$ This realisation of using clan elders' to

\footnotetext{
${ }^{115}$ Bacon, "Strategic Progress Remains Elusive."

${ }^{116}$ Crouch and Ali, "Community Perspectives Towards Al-Shabaab"; Botha and Abdile, "AlShabaab Attitudes"; Toros and Harley, "Negotiations with Al-Shabaab."

${ }^{117}$ Ibrahim Shire, "Negotiating with Somalia's Al Shabab"; Olojo, "Time to Consider Negotiating?"

${ }^{118}$ Robert Press, "Role of Clan Elders Seen as Key to Somali Peace," CS Monitor, February 11, 1993, https://www.csmonitor.com/1993/0211/11022.html.
} 
start dialogue with Al-Shabaab rests on two important points. First, Cronin argues that whilst negotiation with Al-Qaeda is difficult, the organisation is not a monolith, being built on a decentralised network with horizontal connectivity. ${ }^{119}$ Some groups formally affiliated with Al-Qaeda have nationalist tendencies and are not managed from above. Following internal fissures in the early 2010s, the exodus of foreign fighters from Somalia, and the death of Godane, Al-Shabaab is slowly returning to its nationalist tendencies, through different approaches. First, in an attempt to restore popular support and remedy past mistakes, Al-Shabaab's response to the 2017 extreme drought surprised many: the group distributed aid in affected regions, launched drought committees to coordinate relief, and dug canals to help farmers access water for irrigation. ${ }^{120}$ The group has also increasingly been conducting choreographed town visits (including in government-controlled areas) where they distribute alms (zakat) to thousands of poor people.

Second, Al-Qaeda's leadership was surprisingly silent following the death of Godane, a behaviour interpreted by a senior Al-Shabaab defector to mean that Al-Qaeda had cut ties with Al-Shabaab. ${ }^{121}$ However, Al-Shabaab's media campaigns regularly comment on Al-Qaeda operations and Al-Shabaab continues to operationalise orders from Al-Qaeda's central command. The January 2020 Manda Bay airfield raid in Kenya is one example, where Al-Shabaab proudly professed that the order came from AlQaeda's central command. Furthermore, Al-Qaeda central command and other affiliates

\footnotetext{
${ }^{119}$ Cronin, How Terrorism Ends.

${ }^{120}$ Moses Rono, "Somalia food crisis: Has al-Shabab adopted new approach to food aid?" $B B C$, March 22, 2017, https://www.bbc.co.uk/news/world-africa-39296517.

${ }^{121}$ VOA, "VOA oo wareysatay Zakariye Ismaacil,” VOA, March 31, 2015, https://www.voasomali.com/a/interview-with-former-al-shabab/2701194.html.
} 
periodically heap praises on Al-Shabaab's 'heroic' operations in Somalia and beyond. Notwithstanding Al-Shabaab's relatively strong ties with Al-Qaeda and status as a designated terrorist organisation, the group can arguably be reparsed as a nationalistreligious group and, as such, warrants a localised and contextualised approach to negotiation. This localised approach merits the need to utilise national sponsors (i.e., insider-partial mediators) when communicating with violent non-state actors, provided their legitimacy and trust is recognised and respected by both parties to the conflict. ${ }^{122}$ Applying this dialogical approach of including clan elders as possible interlocutors moves past the underlying state-centrism seen in much of the existing work on negotiating with designated terrorist groups.

Nevertheless, the local approach to ending Somalia's protracted stalemate warrants parallel backing from the international community, as Al-Shabaab's senior figures are still under international sanctions. Indeed, Robow and Aweys were placed under house arrest following their disengagement, which served to mollify the justified anger of many Somalis, who still see perceive them as war criminals, but also, and more importantly, satisfied the international community's need to see palpable evidence of senior defectors' ideological 'transformation' and rejection of violent extremism before delisting them. A notable example is Robow's case: he immediately ran for regional presidency in Somalia's South West state, amidst continuing US and UN sanctions, making these bodies and other international governments and bodies uncomfortable, as they wrestled with the prospect of when and how to engage with him if he won. To avoid a similar repeat, adopting the US approach towards the Taliban peace talks might prove beneficial when talking to Al-Shabaab, as it persuaded the UN to suspend

\footnotetext{
${ }^{122}$ See note 119 above.
} 
sanctions against senior leaders of the Taliban whilst the US proposed a set timeline for removing final sanctions - incentives that persuaded the Taliban to commit to the agreement and remove unnecessary roadblocks. ${ }^{123}$

Moreover, since pre-negotiations assumes a more significant weight than formal negotiation. ${ }^{124}$ It serves as a learning process in which both Al-Shabaab and FGS come to understand the needs, interests, and expectations of the opposing party. Since 2008, Al-Shabaab has been persistent in its extreme demands, arguably aware that the Somali government and its international partners would never entertain conceding to these. The demands include the withdrawal of AMISOM troops, the implementation of Sharia law, and for the FGS to recant its 'apostasy' and conform to the group's creed and ideology. However, the pre-negotiation phase affords Al-Shabaab the opportunity to acquaint itself with FGS' intentions and objectives, and to acknowledge possible concessions. The opening phase of such a negotiation will, therefore, inevitably invite concessions from both sides - if this initially comes only from one side, it tends to be reciprocated later on by the other. ${ }^{125}$

Finally, in line with Cronin's concept of sponsor, ${ }^{126}$ which positions credible third-party facilitators as important assets for successful negotiating with groups that employ terrorist tactics, clan elders can initiate and mediate a broader political dialogue that paves the way for direct negotiations. Recognising three important traits, namely accountability, trust, and legitimacy, evidence suggests that clan elders can establish

\footnotetext{
${ }^{123}$ BBC, "Afghan conflict: US and Taliban sign deal to end 18-year war", $B B C$, February 29 , 2020, https://www.bbc.co.uk/news/world-asia-51689443

${ }^{124}$ Pervez N. Ghauri and Jean-Claude. Usunier, International Business Negotiations.

${ }^{125}$ Paul R. Pillar, Negotiating Peace.

${ }^{126}$ See note 9 above.
} 
pre-negotiation by utilising their insider-partial mediator status to facilitate prenegotiation dialogue with Al-Shabaab. 


\section{References}

Amnesty International. “Somalia: A Human Rights Disaster.” London: Amnesty, 1992.

Armengol, V. F. "The Principles of Mediation and the Role of Third Parties in Peace Processes.” Oslo: NOREF, 2013.

Bacon, Tricia. "Strategic Progress Remains Elusive in America's Expanded Air Campaign Against Al-Shabaab."War on the Rocks, March 2018.

Beardsley, Kyle. The Mediation Dilemma. Ithaca: Cornell University Press, 2011.

Botha, A, and Mahdi Abdile. "Al-Shabaab Attitudes Towards Negotiations." In War and Peace in Somalia : National Grievances, Local Conflict and Al-Shabaab, edited by Michael Keating and Matt Waldman, 461-74. London: Hurst Publishers, 2019.

Bradbury, Mark, and Sally Healy. "Whose Peace Is It Anyway? Connecting Somali and International Peacemaking.” Accord Series. Vol. 21. London: Conciliation Resources, 2010.

Butcher, C, and MC Hallward. Understanding International Conflict Management. London: Routledge, 2019.

Carl, Miller. "Is It Possible and Preferable to Negotiate with Terrorists?" Defence Studies 11, no. 1 (2011): 145-85. doi:10.1080/14702436.2011.553109.

Carnevale, Peter. "Mediating from Strength.” In Studies in International Mediation : Essays in Honour of Jeffrey Z. Rubin, edited by Jeffrey Z. Rubin and Jacob. Bercovitch, 25-40. Basingstoke: Palgrave Macmillan, 2002.

Clutterbuck, Richard. "Negotiating with Terrorists." Terrorism and Political Violence 4, no. 4 (1992): 263-87. doi:10.1080/09546559208427186.

Crelinsten, Ronald D., and Alex P. Schmid. Western Responses to Terrorism. London: 
Routledge, 1993.

Cronin, Audrey K. How Terrorism Ends: Understanding the Decline and Demise of Terrorist Campaigns. Princeton: Princeton University Press, 2009.

Crouch, Joanne, and Abdi Ali. "Community Perspectives Towards Al-Shabaab Sources of Support and the Potential for Negotiations." In War and Peace in Somalia: National Grievances, Local Conflict and Al-Shabaab, edited by Michael Keating and Matt Waldman, 449-60. London: Hurst Publishers, 2018.

CTC. “A Profile of Aden Hashi Farah Ayro." CTC Sentinel. West Point, January 1, 2008.

DRC. "Report of the Nordic Fact-Finding Mission to the Gedo Region in Somalia." Copenhagen: DRC, 1999.

Elmi, Afyare Abdi, and Abdi Aynte. "Somalia: The Case for Negotiating with AlShabaab.” Doha: Al Jazeera, 2016.

Faure, Guy Olivier, and William I. Zartman. Negotiating with Terrorists: Strategy, Tactics, and Politics. Abingdon: Routledge, 2010.

Gelot, Linnéa, and Stig Jarle Hansen. "They Are from within Us: CVE Brokerage in South-Central Somalia." Conflict, Security and Development 19, no. 6 (2019): 563-82. doi:10.1080/14678802.2019.1688961.

Göldner-Ebenthal, Karin, and Véronique Dudouet. "Dialogue with Salafi Jihadi Armed Groups: Challenges and Opportunities for Conflict de-Escalation.” Berlin: Berghof Foundation, 2019.

Groeneveld-Savisaar, M, and Sinisa Vuković. “Terror, Muscle, and Negotiation.” In Engaging Extremists: Trade-Offs, Timing, and Diplomacy, edited by William I. Zartman and Guy Olivier Faure, 105-35. Washington: United States Institute of Peace Press, 2011. 
Gundel, J. “The Predicament of the'Oday': The Role of Traditional Structures in Security, Rights, Law and Development in Somalia." Copenhagen: DRC, 2006.

Höglund, Kristine. Peace Negotiations in the Shadow of Violence. Leiden: Martinus Nijhoff Publishers, 2008.

Hussein, Said M-Shidad. "The Impact of the Role of Traditional Leaders on PoliticoGovernance in Somalia: Present Realities and Past Reflections.” Garowe: SIDRA, 2018.

Ibrahim al-Afghani. "Urgent and Open Letter to Our Amiir Shaykh Ayman AlZawahiri.” Islamic World Issues Study Center, April 8, 2013.

Ibrahim Shire, Mohammed. 'Negotiating with Somalia's Al Shabab: It's the Traditional Elders, Stupid.” TRT World, July 8, 2019.

https://www.trtworld.com/opinion/negotiating-with-somalia-s-al-shabab-it-s-thetraditional-elders-stupid-28079.

Ibrahim Shire, Mohammed, and Abdi Hersi. "Brothers in Arms: The Phenomenon of Complex Suicide Attacks.” Terrorism and Political Violence, December 9, 2019, 1-22. doi:10.1080/09546553.2019.1693371.

Interpeace. “A History of Mediationin Somalia since 1988.” Geneva: Interpeace, 2009.

Jones, Seth G., and Martin C. Libicki. How Terrorist Groups End: Lessons For Countering Al Qa'ida. Santa Monica: Rand Publishing, 2008.

la Calle, Luis de, and Ignacio Sánchez-Cuenca. "What We Talk about When We Talk about Terrorism." Politics and Society 39, no. 3 (2011): 451-72. doi:10.1177/0032329211415506.

LaFree, Gary, and Laura Dugan. "Introducing the Global Terrorism Database." Terrorism and Political Violence 19, no. 2 (2007): 181-204. doi:10.1080/09546550701246817. 
Lahoud, Nelly. "The Merger of Al-Shabab and Qa'idat Al-Jihad." West Point: CTC Sentinel, 2012.

Lee, Joel., and Hwee Hwee. Teh. "One Asian Perspective on Mediation." In An Asian Perspective on Mediation, edited by Joel. Lee and Hwee Hwee. Teh, 71-101. Singapore: Academy Publishing, 2009.

Logan, Carolyn. "The Roots of Resilience: Exploring Popular Support for African Traditional Authorities." African Affairs 112, no. 448 (2013): 353-76. doi:10.1093/afraf/adt025.

Marchal, Roland. "A Few Provocative Remarks on Governance in Somalia.” Nairobi: UNDOS, 1998.

Marchal, Roland “A Tentative Assessment of the Somali Harakat Al-Shabaab.” Journal of Eastern African Studies 3, no. 3 (2009): 381-404. doi:10.1080/17531050903273701.

Maruf, Harun, and Dan Joseph. Inside Al-Shabaab: The Secret History of Al-Qaeda's Most Powerful Ally. Bloomington: Indiana University Press, 2018. doi:10.2307/j.ctv6mtfn2.

Menkhaus, Ken. “Governance without Government in Somalia: Spoilers, State Building, and the Politics of Coping." International Security 31, no. 3 (2007): 74 106. doi:10.1162/isec.2007.31.3.74.

Menkhaus, Ken. "Non-State Actors and the Role of Violence in Stateless Somalia." In Violent Non-State Actors in World Politics, edited by Klejda Mulaj, 343-80. London: Hurst Publishers, 2010.

Menkhaus, Ken. "Traditional Conflict Management in Contemporary Somalia." In Traditional Cures for Modern Conflicts: African Conflict Medicine, edited by William I. Zartman, 169-82. Boulder: Lynne Rienner Publishers, 2000.

MGSE. "Letter Dated 7 November 2018 from the Chair of the Security Council 
Committee Pursuant to Resolutions 751 (1992) and 1907 (2009) Concerning Somalia and Eritrea Addressed to the President of the Security Council." New York: UN, 2018.

Michael, George. "The Legend and Legacy of Abu Musab Al-Zarqawi." Defence Studies 7, no. 3 (2007): 338-57. doi:10.1080/14702430701559248.

Mir, Mubashir, and Luxshi Vimalarajah. "Tradition- \& Faith-Oriented Insider Mediators (TFIMs) as Crucial Actors in Conflict Transformation. Potential, Constraints, \& Opportunities for Collaborative Support.” Helsinki: NRTP, 2016.

Murray, Geoffrey, and Oran R. Young. "The Intermediaries: Third Parties in International Crises." International Journal 23, no. 4 (1968): 624. doi:10.2307/40199929.

Olojo, Akinola. “Time to Consider Negotiating with Al-Shabaab in Somalia?” Institute for Security Studies, 2019, June 11.

Powell, Jonathan. Talking to Terrorists : How to End Armed Conflicts. London: Vintage, 2015.

Richmond, Oliver P., and Roger Mac Ginty. "Where Now for the Critique of the Liberal Peace?" Cooperation and Conflict 50, no. 2 (2015): 171-89. doi:10.1177/0010836714545691.

Roepstorff, Kristina, and Anna Bernhard. "Insider Mediation in Peace Processes: An Untapped Resource?" Sicherheit \& Frieden 13, no. 2 (2013): 163-69. doi:10.5771/0175-274x-2013-3-163.

Saferworld. "Forging Jubaland: Community Perspectives on Federalism, Governance and Reconciliation.” London: Saferworld, 2016.

Sahan Africa. "Al-Shabaab as a Transnational Security Threat." In War and Peace in Somalia : National Grievances, Local Conflict and Al-Shabaab, edited by Michael Keating and Matt Waldman, 401-12. London: Hurst Publishers, 2018. 
doi:10.1093/oso/9780190947910.003.0036.

Saunders, Harold H. "We Need a Larger Theory of Negotiation: The Importance of PreNegotiating Phases." Negotiation Journal 1, no. 3 (1985): 249-62. doi:10.1007/BF00999646.

Shinn, David. “Al Shabaab's Foreign Threat to Somalia.” Orbis 55, no. 2 (2011): 20315. doi:10.1016/j.orbis.2011.01.003.

Stein, Janice Gross. "Getting to the Table: Processes of International Prenegotiation." International Journal: Canada's Journal of Global Policy Analysis 44, no. 2 (1989): 231-36. doi:10.1177/002070208904400201.

Svensson, Isak, and Mathilda Lindgren. "Peace from the Inside: Exploring the Role of the Insider-Partial Mediator.” International Interactions 39, no. 5 (2013): 698-722. doi:10.1080/03050629.2013.834261.

Terrorism Research Center. "2005 Terrorism Analysis and Research Report.” Washington: TRC, 2005.

Toros, Harmonie. ““We Don't Negotiate with Terrorists!': Legitimacy and Complexity in Terrorist Conflicts." Security Dialogue 39, no. 4 (2008): 407-26. doi:10.1177/0967010608094035.

Toros, Haromonie, and Stephen Harley. "Negotiations with Al-Shabaab: Lessons Learned and Future Prospects." In War and Peace in Somalia: National Grievances, Local Conflict and Al-Shabaab, edited by Michael Keating and Matt Waldman, 401-11. London: Hurst Publishers, 2018.

Touval, Saadia. The Peace Brokers: Mediators in the Arab-Israeli Conflict, 1948-1979. Princeton: Princeton University Press, 1982.

Ury, L. William. "Getting To Peace: Awakening the Third Side.” In After Terror: Promoting Dialogue Among Civilizations, edited by Akbar S. Ahmed and Brian. Forst, 179-85. London: Polity Press, 2005. 
Wehr, Paul, and John Paul Lederach. "Mediating Conflict in Central America." Journal of Peace Research 28, no. 1 (1991): 85-98. doi:10.1177/0022343391028001009.

Wennmann, Achim. "Negotiated Exits from Organized Crime? Building Peace in Conflict and Crime-Affected Contexts." Negotiation Journal 30, no. 3 (2014): 255-73. doi:10.1111/nejo.12060.

Zartman, William I. Ripe for Resolution: Conflict and Intervention in Africa. Oxford: Oxford University Press, 1989. 